\title{
Velocity of radio waves in glaciers as an indicator of their hydrothermal state, structure and regime
}

\author{
Yu. Ya. Macheret, M. Yu. Moskalevsky, \\ Institute of Geography, Russian Academy of Sciences, Moscow 109017, Russia \\ E. V. VASILENKo \\ The Middle Asia Regional Research Institute of Hydrometeorology, Tashkent, Uzbekistan
}

\begin{abstract}
The results of measurements of radio-wave velocities (RWV) by wide-angle reflection (WAR) methods in the temperate Abramov Glacier in the Alai Mountain Ridge and the "two-layered" sub-polar Fridtjovbreen and Hansbreen on Svalbard using a low-frequency $(2-13 \mathrm{MHz})$ radar are considered and discussed. The experimental data obtained and the data from the literature show that the values of RWV could be a good indicator of the hydrothermal state of glaciers. As such, these data enable the identification of cold, temperate and transitional (two-layered) glaciers, and can be used for estimation of the water content in glaciers and changes in the hydrothermal state.
\end{abstract}

\section{INTRODUCTION}

The RWV in glaciers is an important parameter for calculating ice thickness and depth of the internalreflecting horizons (IRHs) from radio-echo sounding (RES) data. In the radar range (1-1000 MHz), the RWV in a glacier depends on many factors, the most important being density, structure and water content of the ice (Bogorodskiy and others, 1983), and can be noticeably different from the RWV in solid pure ice (e.g. Robin, 1975a; Macheret and Zhuravlev, 1981). Therefore, it is important to obtain field data on the RWV for glaciers having different structures and hydrothermal states. As has been shown in a number of investigations (e.g. Jiracek and Bentley, 1971; Macheret and Zhuravlev, 1985; Kotlyakov and Macheret, 1987), these data can also be used for the calculation of electrical and physical properties of glacier ice.

For the determination of RWV in situ, four basic methods are used: RES in the vicinity of a borehole to bedrock; radio-interferometry and radar logging of a borehole; comparison of the RES and seismic reflectionsounding data; and various modifications of WAR methods (Robin and others, 1969; Trepov, 1970; Drewry, 1975; Robin, 1975b; Bogorodskiy and others, 1983; Jezek and Roellofs, 1983; Macheret and others, 1984a).

The majority of field data on the RWV have been obtained on the polar ice sheets and cold glaciers using radars operating in the UHF and VHF range. They have been summarized by Bogorodskiy and others (1983), Jezek and others (1978) and Robin (1975b). Several measurements have also been carried out on sub-polar glaciers (Ryumin and Zverev, 1969; Zhuravlev and others, 1983; Epov, 1984; Macheret and Zhuravlev,
1985). However, use of this equipment on temperate glaciers, having ice at the melting point and containing a certain amount of water in the interfaces of crystals and in cavities, and in the accumulation areas of a number of sub-polar glaciers with intense summer melting, often becomes ineffective because of the great scattering of radio waves at these wavelengths (Dowdeswell and others, 1984b; Macheret and others, 1984b; Kotlyakov

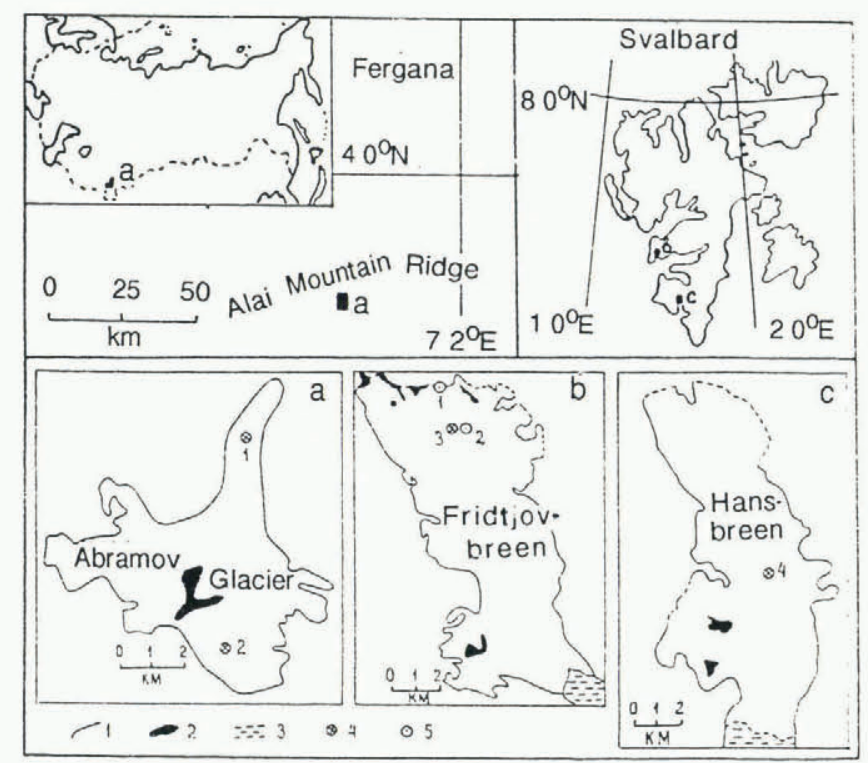

Fig. 1. Low-frequency wide-angle reflection (WAR) measurements on Abramov Glacier in the Alai Mountain Ridge (a), Fridtjovbreen (b) and Hansbreen (c) in Spitsbergen. 1 is the glacier boundary, 2 is ice-free land, 3 is the sea, 4 are WAR-measurement sites and their numbers, and 5 are boreholes and their numbers. 
and Macheret, 1987; Vasilenko and others, 1987; Bamber, 1989). Because of this, the best results on such glaciers can be obtained in the $\mathrm{HF}$ range (Smith and Evans, 1972; Watts and England, 1976) and a number of HF RWV measurements on temperate glaciers have been done (Blindow and Thissen, 1986; Jacobel and others, 1988; Vasilenko and others, 1988b).

Using $\mathrm{HF}$ equipment, RWV measurements were carried out in the summer of 1986 on the temperate Abramov Glacier in the Alai Mountain Ridge (Vasilenko and others, 1988a) and in the spring of 1988 and 1989 on two sub-polar glaciers - Fridtjovbreen and Hansbreen on Svalbard (Glazovskiy and Moskalevskiy, 1989; Glazovskiy and others, 1991a) (Fig. 1).

A specific peculiarity of Fridtjovbreen and Hansbreen is the presence of an extended IRH at depths from 70 to $180 \mathrm{~m}$ (Dowdeswell and others, 1984a; Macheret and others, 1984b). Other glaciers with extended IRHs are found in Spitsbergen (Bamber, 1987, 1989; Macheret, 1990; Macheret and others, 1991). Ice-core, borehole and radar studies on Fridtjovbreen (Macheret and others, 1984a; Kotlyakov and Macheret, 1987) showed that these glaciers are a special class of transitional (two-layered) glacier with the upper layer of "dry" cold ice and a lower layer of water-saturated temperate ice. The extended IRH is an indicator of the location of the melting isotherm in such glaciers (Macheret and Zhuravlev, 1985). The results of the previous determinations of RWV at $620 \mathrm{MHz}$ from ground RES data at borehole 1 (Macheret and others, 1980) and from radar logging of borehole 2 (Macheret and others, 1984a, 1985a) (Fig. 1b) showed considerable differences of RWV within the whole glacier sequence and its upper cold layer-161.4 and $172.2 \mathrm{~m} \mu \mathrm{s}^{-1}$, respectively. The lower mean RWV can be caused by the higher wetness of the snow-firn layer during summer measurements at borehole 1. However, there is no satisfactory explanation for the very low RWV equal to $147.7 \mathrm{~m} \mu \mathrm{s}^{-1}$, determined from the radar logging data in the upper part (in the interval $117-145 \mathrm{~m}$ ) of the lower layer of temperate ice. The new RWV measurements on Fridtjovbreen and Hansbreen were carried out just before melting. They can be used to show to what extent such lower RWV are typical for any two-layered glacier. As a whole, the series of investigations on all the above-mentioned glaciers provides the possibility of determining RWV in both cold and temperate ice, and of comparing them with the results of independent measurements on other glaciers.

\section{CHARACTERISTICS OF RWV MEASUREMENT SITES}

Details on Abramov Glacier, Fridtjovbreen and Hansbreen are given in Table 1 . Site 3 on Fridtjovbreen was situated at a distance about $500 \mathrm{~m}$ from borehole 2 drilled

Table 1. Characteristics of measurement sites and the methods of wide-angle reflection on Abramov Glacier, Fridtjovbreen and Hansbreen

\begin{tabular}{|c|c|c|c|c|c|c|c|c|c|c|}
\hline \multirow[t]{3}{*}{ Glacier } & \multirow{3}{*}{$\begin{array}{l}\text { Number } \\
\text { of site }\end{array}$} & \multirow{2}{*}{ Altitude } & \multirow{3}{*}{$\begin{array}{l}\text { Area of the } \\
\text { glacier }\end{array}$} & \multicolumn{2}{|c|}{ Previous data } & \multicolumn{5}{|c|}{ WAR measurements } \\
\hline & & & & $\begin{array}{c}\text { Ice } \\
\text { thickness }\end{array}$ & $\begin{array}{l}\text { Depth of } \\
\text { IRH }\end{array}$ & $\begin{array}{l}\text { Date of } \\
\text { measure- } \\
\text { ment }\end{array}$ & $\begin{array}{l}\text { Type of } \\
\text { antennas }\end{array}$ & $\begin{array}{l}\text { Arrange- } \\
\text { ment of } \\
\text { antennas }\end{array}$ & $\begin{array}{c}\text { Interval of } \\
\text { measure- } \\
\text { ments } \\
\Delta \ell\end{array}$ & $\begin{array}{c}\text { Distance } \\
\text { between } \\
\text { antennas } \\
\ell\end{array}$ \\
\hline & & $\mathrm{m}$ & & $\mathrm{m}$ & $\mathrm{m}$ & & & & $\mathrm{m}$ & $\mathrm{m}$ \\
\hline \multirow[t]{2}{*}{ Abramov } & 1 & 3700 & Ablation & $\sim 130^{1}$ & - & 25.6 .1986 & $\mathrm{R}$ & Co-linear & 4 & $20-188$ \\
\hline & 2 & 4400 & $\begin{array}{l}\text { Accumulation, } \\
\text { warm zone }\end{array}$ & $\sim 220^{1}$ & - & 21.7.1986 & $\mathrm{L}$ & Co-linear & 4 & $28-128$ \\
\hline $\begin{array}{l}\text { Fridtjov- } \\
\text { breen }\end{array}$ & 3 & 380 & $\begin{array}{l}\text { Accumulation, } \\
\text { zone of super- } \\
\text { imposed ice }\end{array}$ & $\sim 250^{2}$ & $125^{4} \pm 10$ & 6.5 .1988 & $\mathrm{R}$ & Co-linear & 4 & 18-202 \\
\hline Hansbreen & 4 & 310 & $\begin{array}{l}\text { Accumulation, } \\
\text { zone of super- } \\
\text { imposed ice }\end{array}$ & $\sim 370^{3}$ & $\sim 130^{5}$ & 12.6.1989 & $\mathrm{R}$ & Parallel & 4 & $16-220$ \\
\hline
\end{tabular}

Notes:

${ }^{1}$ Ground HF RES survey in 1986 (Vasilenko and others, 1988a).

${ }^{2}$ Ground HF RES survey in 1988 (Glazovskiy and Moskalevskiy, 1989).

${ }^{3}$ Ground HF RES survey in 1989 (Glazovskiy and others, 1991b).

${ }^{4}$ Ground $620 \mathrm{MHz}$ RES in 1988 (Glazovskiy and Moskalevskiy, 1989).

${ }^{5}$ Airborne $620 \mathrm{MHz}$ and $60 \mathrm{MHz}$ RES in 1979 and 1980, respectively (Dowdeswell and others, 1984a; Macheret and others, 1984b). 
in 1979 (Fig. 1b). RES and radar logging to a depth of $145 \mathrm{~m}$ at a frequency of $620 \mathrm{MHz}$, as well as temperature measurements and ice-core studies to depths of 115 and $119 \mathrm{~m}$, showed the following (Macheret and Zhuravlev, 1985; Macheret and others, 1985b): IRH depth is

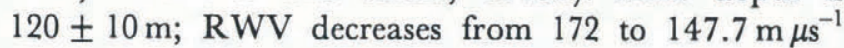
and ice temperature rises to the pressure-melting point at depths of more than $117 \pm 12 \mathrm{~m}$ and $113 \mathrm{~m}$, respectively; and microchannels characteristic of temperate ice were observed in the depth interval $110-116 \mathrm{~m}$. At site 3 , the IRH depth was found to be $125 \pm 10 \mathrm{~m}$ in 1988 by using ground RES data at a frequency of $620 \mathrm{MHz}$ (Glazovskiy and Moskalevskiy, 1989) confirming the previous airborne and ground RES data at frequencies of 620 and $60 \mathrm{MHz}$ (Dowdeswell and others, 1984a; Macheret and others, 1984b).

Fridtjovbreen has a similar structure in the vicinity of borehole 1 which was drilled in 1975 to bedrock. Reflections from a strong IRH at $620 \mathrm{MHz}$ at a depth of $72 \pm 5 \mathrm{~m}$ were recorded (Macheret and others, 1984b; Macheret and Zhuravlev, 1985). A rise in temperature to the pressure-melting point at a depth of about $80 \mathrm{~m}$ was recorded, and inflow of liquid water into the borehole was observed between 58 and $81 \mathrm{~m}$. However, the HF RES survey of 1988 did not show the internal reflections at the majority of measurement points on Fridtjovbreen including WAR site 3 and its environs (Glazovskiy and others, 1991b).

On Hansbreen, at site 4 the depth of the IRH according the airborne RES in 1979 at a frequency of $620 \mathrm{MHz}$ (Macheret and others, 1984b) and in 1980 at a frequency of $60 \mathrm{MHz}$ (Dowdeswell and others, 1984a) is about $130 \mathrm{~m}$. Internal reflections from shallower and greater depths were recorded at the majority of HF RES survey points on Hansbreen in 1989 (Glazovskiy and others, 1991a). The data from a longitudinal profile crossing site 4 illustrate this peculiarity (Fig. 2). At site 4, the depths of internal HF reflections are 125, 165 and $200 \mathrm{~m}$. Direct exploration of several moulins located at distances of 4-5 km from site 4 was made in the autumn of 1988 and in the spring and autumn of 1989 (Schroeder, 1990; personal communication from J. Jania and M.

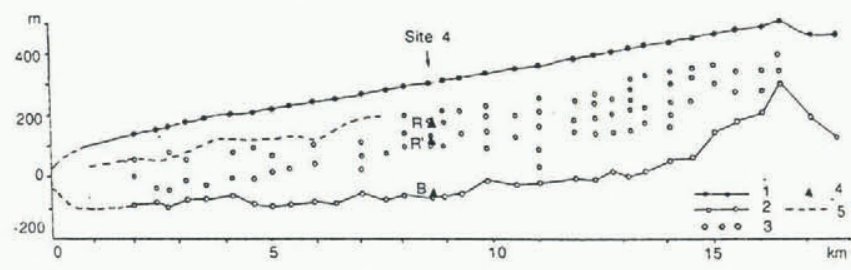

Fig. 2. Longitudinal profile of Hansbreen from data of ground low-frequency radio-echo sounding (HF RES). 1 are glacier-surface and measurement points of ground $H F$ RES survey in 1989 (Glazovskiy and others, 1991a); 2 and 3 are correspondingly the bottom and internal reflections from the same data; 4 are data of $H F$ wideangle reflection measurements at site 4 in 1989 (see Tables 2 and 3): $R$ and $R^{\prime}$ are the lower and upper internal reflection boundaries, $B$ is glacier bottom; 5 is internalreflection horizon (IRH) from data of airborne RES at $620 \mathrm{MHz}$ in 1979 (Macheret and others, 1984b) and at $60 \mathrm{MHz}$ in 1980 (Dowdeswell and others, 1984a).
Pulina). These show that at depths of $90-120 \mathrm{~m}$ there are inclined channels $5-20 \mathrm{~m}$ high and $1-5 \mathrm{~m}$ wide with several ledges and water pools of meter scale. Thus, the depths of the internal $\mathrm{HF}$ reflections and of the IRH are very similar to the upper boundary of this zone, with water inclusions inside the glacier.

\section{EQUIPMENT AND RWV MEASUREMENT METHOD}

A monopulse HF radar (MP1-8) with shock excitation of the aerials developed at Mary Polytechnic Institute was used for the measurements (Vasilenko and others, 1988b). The transmitted signal spectrum is $2-13 \mathrm{MHz}$, the central frequency is $8 \mathrm{MHz}$ and the pulse power is $13 \mathrm{~kW}$. Active and reactively loaded dipoles ( $\mathrm{R}$ - and L-antennas) $16 \mathrm{~m}$ and $28 \mathrm{~m}$ long, respectively, served as transmitting and receiving antennas.

The common midpoint (CMP) method was used for RWV measurements, i.e. the transmitted and receiving antennas were moved away with a certain interval $\Delta \ell$ at equal distance $\ell / 2$ with respect to the fixed centre of the antenna arrangement. In this case, the influence of the bed inclination on the accuracy of determination of the mean RWV is small, because radio-wave reflection occurs approximately at the same point on the glacier bed.

Type and arrangement of antennas, and values of $\Delta \ell$ and $\ell$ for the measurement sites, are given in Table 1 .

Recording of returns on all sites was made by photographing the screen of an oscilloscope. Scanning speed was calibrated with the aid of a quartz signal generator with a time repetition of $0.2 \mu \mathrm{s}$. Autotriggering was carried out with direct waves radiated by the transmitting antenna.

\section{THE RESULTS OF RWV MEASUREMENTS}

Some examples of records obtained on Abramov Glacier at sites 1 and 2 are given in Figure $3 a$ and $b$. Two groups of regular signals can be distinguished easily: signals $\mathrm{A}$ and $\mathrm{N}$ propagated directly from the transmitting to the receiving antenna, one through air and the other within the near-surface glacier sequence; and returns B from the glacier bed. In addition, at some antenna separations, there are signals $I$ due to reflections from the glacier surface and/or internal inhomogeneities. At site 1, signals $\mathrm{A}$ and $\mathrm{N}$ are observed separately at distances between antennas $\ell>28 \mathrm{~m}$; at site 2 , with $\ell>44 \mathrm{~m}$. At shorter distances these interfere with each other forming signals $A+N$. At site 1 , returns from the glacier bed are observed at $\ell \leq 168 \mathrm{~m}$; at site 2 , at $\ell \leq 128 \mathrm{~m}$. At greater distances their amplitude at site 1 becomes comparable with the noise.

On Fridtjovbreen and Hansbreen (sites 3 and 4), the bottom signals B were observed at a greater distance between antennas - up to 202 and $220 \mathrm{~m}$, respectively (Fig. 3c and d), which indicates their lower total attenuation during propagation and reflection as compared with site 1 on Abramov Glacier. In addition, on Hansbreen at site 4 and $\ell \leq 220 \mathrm{~m}$, unambiguous signals $\mathrm{R}$ from an internal interface were detected and less clearly 


\section{Abramov Glacier}
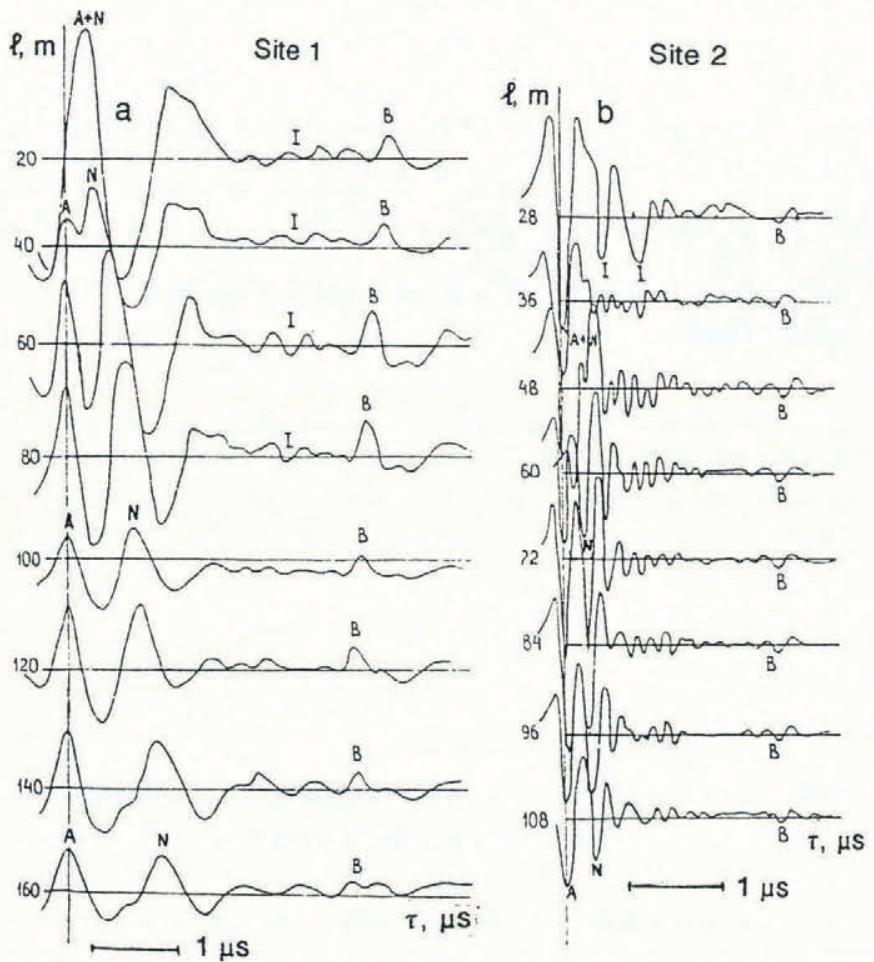

Fridtjovbreen

Hansbreen
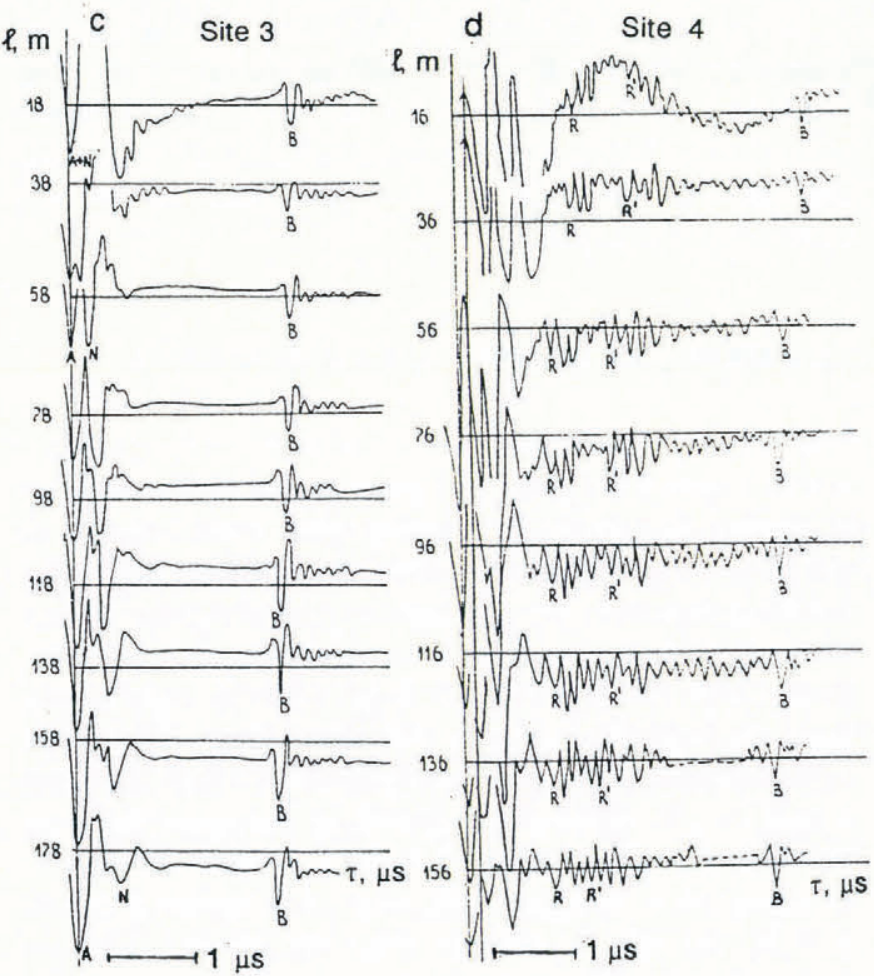

Fig. 3. Examples of radio-oscillograms obtained by lowfrequency wide-angle reflection measurements on Abramov Glacier at sites $1 a$ and $2 b$, on Fridtjovbreen at site $3 c$, and Hansbreen at site $4 d$. $A$ and $\mathcal{N}$ are correspondingly signals propagating from the transmitting to the receiving antenna, one through air and the other within the near-glacier sequence; $A+\mathcal{N}$ is interference of signals $A$ and $\mathcal{N} ; B$ is bottom return; $R$ and $R^{\prime}$ are signals from internalreflection boundaries; I is signal from near-surface and/or internal inhomogeneities. signals $R^{\prime}$ from a deeper internal interface were distinguished.

For a simple two-dimensional model of a glacier as a homogeneous isotropic ice layer with a plane interface, the full delay time of bottom returns $B$ in the approximation of geometrical optics using the CMP method is (Gurvich, 1975):

$$
\tau_{\mathrm{B}}=\frac{1}{V_{\mathrm{B}}} \sqrt{4 h_{\mathrm{B}}^{2}+\ell^{2} \cos ^{2} \varphi_{\mathrm{B}}}
$$

where $\tau_{\mathrm{B}}=\tau_{\mathrm{d}}+\tau_{0}, \tau_{\mathrm{d}}$ is the delay time of the bottom signal B measured relative to the signal $\mathrm{A}, \tau_{0}=c / \ell$ is the propagation time in air of signal A from the transmitter, $c$ is the RWV in air, $V_{\mathrm{B}}$ is the mean velocity of the bottom signal $\mathrm{B}, h_{\mathrm{B}}$ is the echo depth of the bottom and $\varphi_{\mathrm{B}}$ is the difference in slope angles of the glacier surface and the glacier bed (subject to their sign). $\varphi_{\mathrm{B}}$ was determined from geodetic surveys and RES data in the vicinity of the WAR sites.

Equation (1) can be transformed to a linear form

$$
y=a x+b
$$

by squaring and assigning

$$
y=\tau_{\mathrm{B}}^{2}, x=\ell^{2}, a=\cos ^{2} \varphi_{\mathrm{B}} / V_{\mathrm{B}}^{2}, b=4 h_{\mathrm{B}}^{2} / V_{\mathrm{B}}^{2} .
$$

A least-squares procedure may easily be used to find the values of $V_{\mathrm{B}}$ and $h_{\mathrm{B}}$ :

$$
\begin{aligned}
& V_{\mathrm{B}}=\sqrt{1 / a} \cos \varphi_{\mathrm{B}}, \\
& h_{\mathrm{B}}=\frac{1}{2} \sqrt{b / a} \cos \varphi_{\mathrm{B}} .
\end{aligned}
$$

The velocity of signals $N, R$ and $R^{\prime}$ and the echo depth of their penetration into the glacier can be found in an analogous way.

The results of WAR measurements at sites 1, 2, 3 and 4 are shown in Figures 4 and 5 in the form of the regression $\tau^{2}=f\left(\ell^{2}\right)$. From these figures, it is seen that the results are almost linear except at smaller $\ell^{2}$. This phenomenon can be explained by the following two reasons. For signals $B$, the decrease of delay time in the initial parts of graphs $\tau=f\left(\ell^{2}\right)$ results mainly from interference of signals A and N. For site 1, the interference takes place at $\ell \leq 28 \mathrm{~m}$, at site 2 at $\ell \leq 36 \mathrm{~m}$, at site 3 at $\ell \leq 18 \mathrm{~m}$ and at site 4 at $\ell \leq 104 \mathrm{~m}$. The wider area of interference at site 4 results from the parallel alignment of antennas. For signals $R$ and $R^{\prime}$ at site 4 , the delay time in the initial part of the graph at $\ell \leq 54 \mathrm{~m}$, on the contrary, increases (Fig. 5b). This can be explained by the apparent dependence of the reflecting boundary depth on the angle of radio-wave incidence, i.e. on distance $\ell$ between the antennas, and probably results from the smooth change of dielectric permittivity of glacier ice through the depth of the glacier which occurs because of the presence of waterfilled cavities. These peculiarities in the initial parts of graphs $\tau^{2}=f\left(\ell^{2}\right)$ were often observed during WAR measurements on glaciers both in the Arctic and Antarctic (Fedorov, 1978; Bogorodskiy and others, 1983). For this reason, low abscissa values were excluded from further processing using the least-squares procedure.

The results of processing WAR data at sites 1, 2, 3 and 4 for signals $N, R$ and $R^{\prime}$ using Equations (1)-(5) are given in Table 2. For these signals we assume $\varphi_{\mathrm{N}}=\varphi_{\mathrm{R}}=$ $\varphi_{\mathrm{R}^{\prime}}=0$. 


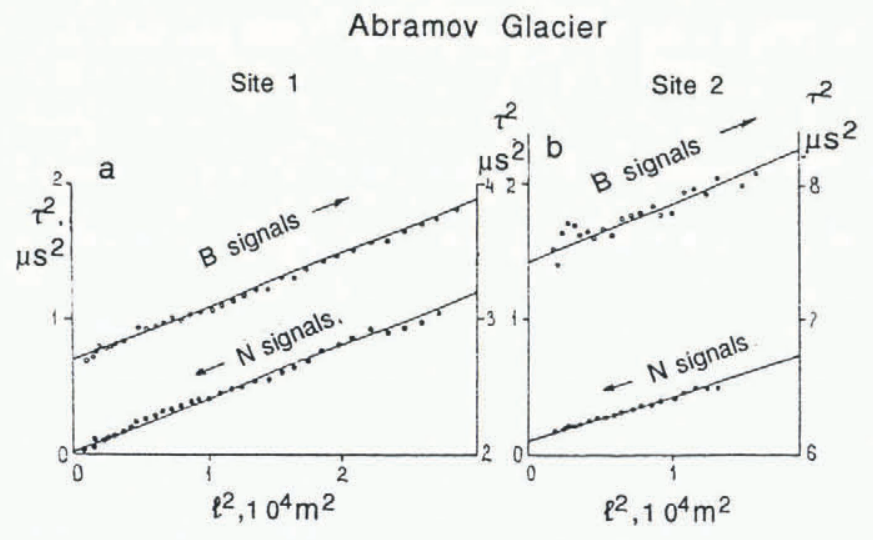

Fig. 4. Graphs of delay-time $y=\tau^{2}$ dependence of signals on the distance $x=\ell^{2}$ between antennas, obtained during wide-angle reflection measurements on Abramov Glacier at sites $1 a$ and $2 b$ for signals $\mathcal{N}$ propagating within the nearsurface glacier sequence and for bottom signals $B$.

\section{DISGUSSION OF THE RESULTS}

\section{Radio-wave velocity-depth profiles of glaciers}

On the tongue of Abramov Glacier (site 1), velocities of signals $\mathrm{N}$ and $\mathrm{B}$ do not differ significantly from each other (Table 2), although the directions and depths of propagation of these signals into the glacier are different. Thus, in the ablation area, the RWV does not change through the glacier depth, and the average RWV is $160.3 \pm 1.0 \mathrm{~m} \mathrm{~ms}^{-1}$. However, it is still not clear why the depth of penetration into the glacier of signals $\mathrm{N}$ equals $13.8 \mathrm{~m}$ instead of zero for a direct wave through the ice.

In the accumulation area of Abramov Glacier (site 2), the velocities of signals $\mathrm{N}$ and $\mathrm{B}$ differ from each other because of the presence of a firn layer. The velocity of signals $\mathrm{N}\left(V_{\mathrm{N}}=182.3 \pm 1.6 \mathrm{~m} \mu \mathrm{s}^{-1}\right)$ is close to the average velocity of broad-band $(4-330 \mathrm{MHz})$ electromagnetic signals in the nearby snowpack of about $190 \mathrm{~m} \mu \mathrm{s}^{-1}$ signals in the nearby snowpack of about $190 \mathrm{~m} \mu \mathrm{s}^{-1}$ (Gromyko and others, 1989). Pit data showed that thickness of the snow-firn layer near site 2 exceeds $25 \mathrm{~m}$ (Krenke and Suslov, 1980), which agrees with the result that the depth of penetration of signals $\mathrm{N}$ into the glacier $h_{\mathrm{N}}=32.5 \mathrm{~m}$. Taking this into account, the velocitydepth section of Abramov Glacier at this site can be considered as two-layered.

According to the results from both the ground RES and the radar logging of the nearby borehole 2 (see Fig. 1b) at $620 \mathrm{MHz}$, the velocity-depth section of Fridtjovbreen at site 3 can also be considered as two-layered: velocity $V_{1}$, in the upper layer of cold ice, is equal to $172.2 \mathrm{~m} \mu \mathrm{s}^{-1}$ and the thickness of this layer $h_{1}$ is $125 \pm 10 \mathrm{~m}$.

For Hansbreen, two models were considered: twolayered (1) and three-layered (2) (Fig. 6). In the latter case, the less prominent and deeper internal signal $\mathrm{R}^{\prime}$ was taken into account.

Assuming absence of radio-wave refraction at the boundary of englacial layers, the velocity $V_{2}$ in the underlying layer corresponding to the snow-firn layer at site 2 and the internal reflecting boundaries at sites 3 and 4 can be calculated as

$$
V_{2}=\frac{\left(h-h_{1}\right) V_{1} V_{\mathrm{m}}}{h V_{1}-h_{1} V_{\mathrm{m}}} .
$$

The equation for the velocity $V_{2}^{\prime}$ in the ice layer underlying the internal boundary at site 4 can be calculated as

$$
V_{2}^{\prime}=\frac{\left(h-h_{1}\right) h_{1}{ }^{\prime} V_{\mathrm{m}}}{h V_{1}^{\prime}-V_{1}^{\prime} V_{\mathrm{m}}} .
$$

and the velocity $V_{1-2}$ in the intermediate layer 1-2 (between boundaries $\mathrm{R}$ and $\mathrm{R}^{\prime}$ at site 4 ) is equal to

$$
V_{1-2}=\frac{\left(h_{1}^{\prime}-h_{1}\right) V_{1}^{\prime} V_{1}}{h_{1}^{\prime} V_{1}-h_{1} V_{1}^{\prime}}
$$

where $h=h_{\mathrm{B}}, V_{\mathrm{m}}=V_{\mathrm{B}}, h_{1}=h_{\kappa}, V_{1}=V_{\kappa}(\kappa=\mathrm{N}, \mathrm{R})$, $h_{1}^{\prime}=h_{\mathrm{R}^{\prime}}, V_{1}^{\prime}=V_{\mathrm{R}^{\prime}}$.

The results of calculations of velocities $V_{2}, V_{2}^{\prime}$ and $V_{1-2}$ by Equations (6) are given in Table 3 as corresponding velocity-depth sections. The errors in determining $V_{\mathrm{B}}, V_{\mathrm{R}}$ and $V_{\mathrm{R}^{\prime}}$ by a least-squares procedure and Equations (1)-(5) were taken into account.

In media with weak absorption such as pure ice, air and water, dispersion within the RES range is negligible, i.e.
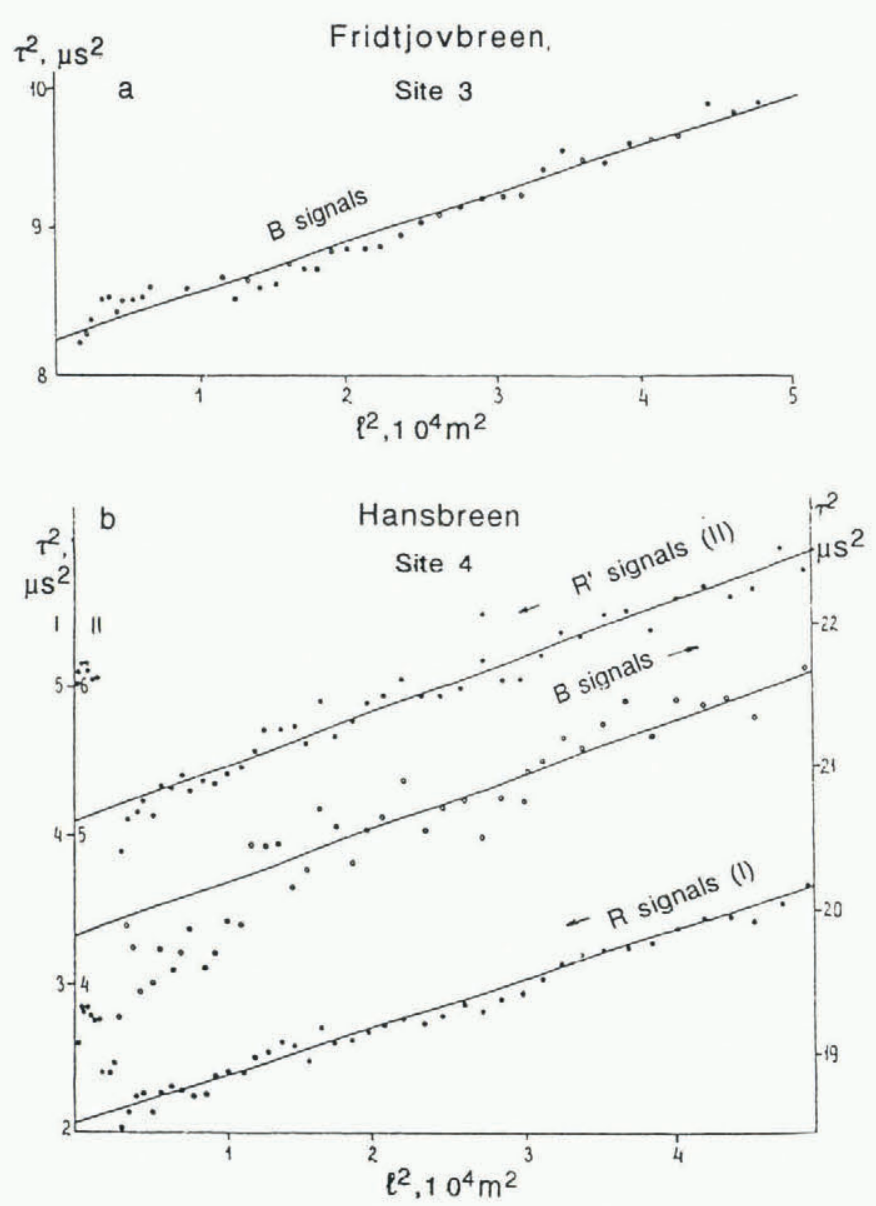

Fig. 5. Graphs of delay-time $y=\tau^{2}$ dependence of signals on the distance $x=\ell^{2}$ between antennas, obtained during wide-angle reflection measurements on Fridtjovbreen at site 3 (a) for bottom signals $B$ on Hansbreen at site 4 (b) for bottom signals $B$, and for signals $R$ and $R^{\prime}$ from internalreflection boundaries. 
Table 2. The results of processing data of wide-angle reflection measurements on Abramov Glacier, Fridtjovbreen and Hansbreen

\begin{tabular}{|c|c|c|c|c|c|c|c|c|}
\hline Glacier & Number of sites & Type of signal & $n$ & $\begin{array}{c}V^{*} \pm \Delta V^{*} \\
\mathrm{~m} \mu \mathrm{s}^{-1}\end{array}$ & $\begin{array}{c}h \pm \Delta h \\
\mathrm{~m}\end{array}$ & $r$ & $\begin{array}{c}\varphi \\
\operatorname{deg}\end{array}$ & $\begin{array}{r}V \pm \Delta V \\
\mathrm{~m} \mu \mathrm{s}^{-1}\end{array}$ \\
\hline \multirow{4}{*}{$\begin{array}{c}\text { Abramov } \\
\text { Glacier }\end{array}$} & \multirow[t]{2}{*}{1} & B & 34 & $160.6 \pm 1.0$ & $131.7 \pm 1.0$ & 0.997 & 3.8 & $160.3 \pm 1.0$ \\
\hline & & $\mathrm{N}$ & 33 & $161.3 \pm 0.9$ & $13.8 \pm 1.7$ & 0.997 & $\sim 0$ & $161.3 \pm 0.9$ \\
\hline & \multirow[t]{2}{*}{2} & B & 22 & $161.3 \pm 6.9$ & $220.4 \pm 1.0$ & 0.935 & 2.2 & $161.2 \pm 6.9$ \\
\hline & & $\mathrm{N}$ & 19 & $182.3 \pm 1.6$ & $32.5 \pm 0.5$ & 0.997 & 0 & $181.3 \pm 1.6$ \\
\hline Fridtjovbreen & 3 & B & 45 & $172.2 \pm 2.1$ & $247.4 \pm 0.3$ & 0.987 & $\sim 10$ & $169.6 \pm 2.1$ \\
\hline \multirow[t]{3}{*}{ Hansbreen } & \multirow[t]{3}{*}{4} & B & 29 & $165.4 \pm 5.9$ & $368.4 \pm 0.7$ & 0.939 & $<1$ & $165.4 \pm 5.9$ \\
\hline & & $\mathrm{R}$ & 42 & $176.8 \pm 1.9$ & $126.8 \pm 0.6$ & 0.991 & $\sim 0$ & $176.8 \pm 1.9$ \\
\hline & & $\mathrm{R}^{\prime}$ & 42 & $165.4 \pm 3.4$ & $186.7 \pm 0.7$ & 0.843 & $\sim 0$ & $165.4 \pm 3.4$ \\
\hline
\end{tabular}

Note: $n$ is the number of measurement points used for the calculation; $\Delta V^{*}, \Delta V$ and $\Delta h$ are errors of determination of velocities $V^{*}=V_{\mathrm{B}} / \cos \varphi_{\mathrm{B}}, V$ and echo depth $h$, respectively; $r$ is the correlation coefficient. The other symbols are defined in the text.

$$
V=c / \sqrt{\epsilon}
$$

where $\epsilon$ is the real part of the complex dielectric permittivity of the medium. This makes it possible to compare data from field RWV measurements at different frequencies in other glaciers and data from laboratory measurements of $\epsilon$ (Fig. 7).

Analysis of Table 3 and Figure 7 shows that the mean velocities $V_{\mathrm{m}}$ through the whole ice sequence of twolayered glaciers that have been investigated are higher than in the temperate Abramov Glacier, but are lower than on the majority of cold ice sheets and glaciers where there are data from field measurements in the range 30$620 \mathrm{MHz}$. On Hansbreen, the velocity $V_{2}$ in the lower layer is close to the mean velocity $V_{\mathrm{m}}$ in the temperate Abramov Glacier but lower than on Fridtjovbreen. This can be explained by the presence of an intermediate layer on Hansbreen at site 4 (layer 1-2 in model (2); see Fig. 6b a

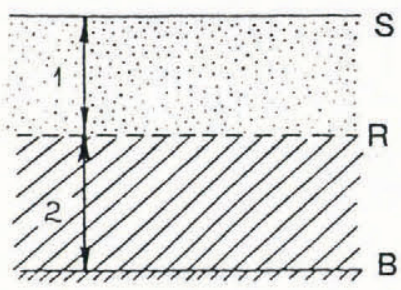

b

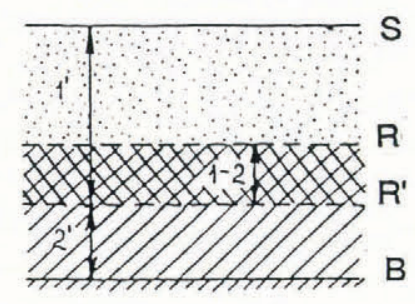

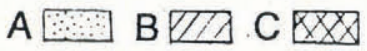

Fig. 6. Velocity-depth section of Hansbreen at site 4 of wide-angle reflection measurements for two-layered model 1 (a) and three-layered model 2 (b). $A$ is "dry" cold ice, $B$ is water-saturated temperate ice, $C$ is intermediate layer in temperate ice. $S$ and $B$ are correspondingly surface and bottom of glacier, $R$ and $R^{\prime}$ are internal-reflection boundaries. and Table 3) c. $60 \mathrm{~m}$ thick with a lower velocity $V_{1-2}=$ $145.5 \pm 5.5 \mathrm{~m} \mathrm{ss}^{-1}$. This layer is at depths between 127 and $187 \mathrm{~m}$. It should be mentioned that a similar value of velocity $V_{2}^{\prime \prime}=147.7 \mathrm{~m} \mu \mathrm{s}^{-1}$ was obtained in the upper part of the lower layer 2 on Fridtjovbreen from data of the radar logging of borehole 2 in the summer of 1979 within the depth interval $117-145 \mathrm{~m}$ at $620 \mathrm{MHz}$ (Macheret and others, 1984a; Kotlyakov and Macheret, 1987).

Data from the 1989 survey (Fig. 2) give additional information concerning the location of the intermediate layer on Hansbreen. These show that internal reflections can be traced along almost all of the entire longitudinal profile at depths from 100-160 to $160-320 \mathrm{~m}$. Assuming that the shallowest and deepest internal reflections shown in Figure 2 have the same nature as reflected signals $\mathbf{R}$ and $\mathrm{R}^{\prime}$ at site 4 , the thickness of this layer is $60-220 \mathrm{~m}$. The presence of only a single extended IRH, i.e. internal reflections from the upper boundary of the intermediate layer, can be explained by strong scattering of radio waves at these frequencies within this layer.

The data in Figure 7 indicate great variability of RWV in cold glaciers. Also, the majority of field measurements give values $V$ higher ( $\epsilon$ lower) than the laboratory measurements. This is especially noticeable in measurements on ice shelves, but the cause of such differences has not yet been determined (Bogorodskiy and others, 1983). The most reliable lower limit of RWV in cold ice is $167.7 \pm 0.3 \mathrm{~m}_{\mu}^{-1}$ and comes from radiointerferometry measurements in a borehole on the Devon Ice Cap at about $425 \mathrm{MHz}$ (Robin, 1975b). This corresponds to a value of $\epsilon=3.20 \pm 0.1$.

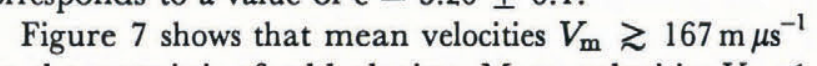
are characteristic of cold glaciers. Mean velocities $V_{\mathrm{m}} \lesssim$ $167 \mathrm{~m}^{-1} \mathrm{~s}^{-1}$ are typical of temperate glaciers. On twolayered glaciers, velocities $V_{1}$ in the upper layer (negative temperatures) are higher than velocities $V_{2}$ in the lower layer, where temperatures are close to or equal to the 
Table 3. Velocity-depth sections of Abramov Glacier, Fridtjovbreen and Hansbreen from the data from wide-angle reflection measurements and physical characteristics of the glacier sequence estimated from these data

\begin{tabular}{cccccc} 
Layer & Parameter of & \multicolumn{2}{c}{ Abramov Glacier } & Fridtjovbreen & Hansbreen \\
depth section & Site 1 & Site 2 & Site 3 & Site 4 Model (1) Model (2)
\end{tabular}

\begin{tabular}{|c|c|c|c|c|c|}
\hline $\begin{array}{l}\text { The whole } \\
\text { sequence }\end{array}$ & $\begin{array}{c}h(\mathrm{~m}) \\
V_{\mathrm{m}}\left(\mathrm{m} \mu \mathrm{s}^{-1}\right) \\
W_{\mathrm{m}}(\%)\end{array}$ & $\begin{array}{c}131.7 \pm 1.0 \\
160.3 \pm 1.0[38] \\
1.69 \pm 0.21 \\
(1.27 \pm 0.15)\end{array}$ & 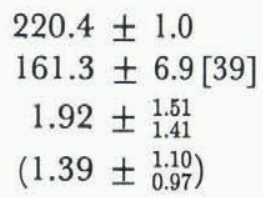 & $\begin{array}{l}247.4 \pm 0.3 \\
169.6 \pm 2.1[41]\end{array}$ & $\begin{array}{l}368.4 \pm \\
165.4 \pm\end{array}$ \\
\hline 1 & $\begin{array}{c}h_{\mathrm{i}}(\mathrm{m}) \\
V_{1}\left(\mathrm{~m} \mathrm{~s}^{-1}\right) \\
\rho_{1}\left(\mathrm{~kg} \mathrm{~m}^{-3}\right) \\
W_{1}(\%)\end{array}$ & & $\begin{array}{c}0.49 \pm 0.27 \\
(0.25 \pm 0.17)\end{array}$ & $\begin{array}{c}125 \pm 10^{(1)} \\
172.2^{(2)}[42] \\
867 \\
(873)\end{array}$ & $\begin{aligned} & 126.8 \pm 0.6 \\
& 176.8 \pm 1.9[45] \\
& 818 \pm 20 \\
&(820 \pm 21)\end{aligned}$ \\
\hline 2 & $\begin{array}{c}h-h_{1}(\mathrm{~m}) \\
V_{2}\left(\mathrm{~m} \mu \mathrm{s}^{-1}\right) \\
W_{2}(\%)\end{array}$ & & $\begin{array}{c}187.9 \\
158.1 \pm 7.5[40] \\
2.16 \pm 1.72\end{array}$ & $\begin{array}{c}122.4 \\
167.3 \pm 4.3[43] \\
0.17 \pm 0.88\end{array}$ & $\begin{array}{c}241.6 \\
160.0 \pm 7.6[46] \\
1.68 \pm 1.71\end{array}$ \\
\hline & & & $\left(1.61 \pm{ }_{1.10}^{1.28}\right)$ & $\left(0.22 \pm{ }_{0.22}^{0.60}\right)$ & $\left(1.27 \pm \begin{array}{l}1.25 \\
1.09\end{array}\right)$ \\
\hline
\end{tabular}

$1^{\prime} \quad h_{1}^{\prime}(\mathrm{m})$

$$
V_{1}^{\prime}\left(\mathrm{m} \mu \mathrm{s}^{-1}\right)
$$

$2^{\prime} \quad h-h_{1}^{\prime}(\mathrm{m})$

$$
\begin{gathered}
\left.V_{2}^{\prime} \mathrm{m} \mu \mathrm{s}^{-1}\right) \\
W_{2}^{\prime}(\%)
\end{gathered}
$$

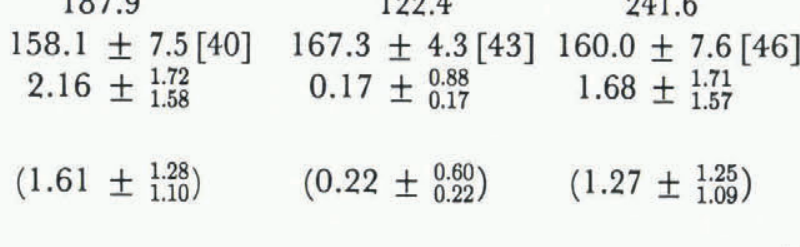

$186.7 \pm 0.7$

$165.4 \pm 3.4$ [47]

181.7

$165.4 \pm 8.5$ [48]

$0.56 \pm 0.55$

$\left(0.48 \pm \begin{array}{l}1.28 \\ 0.48\end{array}\right)$

$1-2 \quad h_{1}^{\prime}-h_{1}(\mathrm{~m})$
$V_{1-2}\left(\mathrm{~m} \mu \mathrm{s}^{-1}\right)$
$W_{1-2}(\%)$

59.9

$145.5 \pm 5.5$

$5.06 \pm 1.34$

$(3.83 \pm 1.10)$

Note: (1) and (2) are data of ground RES (Glazovskiy and Moskalevskiy, 1989) and radar logging of borehole 2

(Macheret and others, 1984a), respectively, at a frequency of $620 \mathrm{MHz}$. The values of $\rho$ and $W$ are calculated using Equations (13), (8), (15) and (10) (the latter are given in round brackets). RWVs are denoted by figures in square brackets and are numbered in Figure 7.

pressure-melting point. However, as measurements on Fridtjovbreen near borehole 1 show, during the melting period mean velocity $V_{\mathrm{m}}$ in two-layered glaciers can increase to the values characteristic of temperate glaciers.

All these data indicate the high sensitivity of RWV to even small amounts of water in the glacier sequence and, on the basis of the magnitude and character of velocity changes with depth, support the idea of classifying glaciers according to their hydrothermal state, i.e. of identifying cold, temperate and transitional (two-layered) parts of glaciers. Also, Equation (7) makes it possible to use data from RWV measurements to estimate physical parameters of the glacier sequence by applying theoretical or empirical dependences of the dielectric permit- tivity $\epsilon$ on density; wetness and structure of glacier ice, firn and snow; content and geometry of various inclusions and impurities, and their distribution as described by Beek (1967) and Bogorodskiy and others (1983).

In the subsequent analysis of the data obtained, we confine ourselves to considering such important parameters as the mean density and average water content.

\section{Estimation of physical parameters of the glacier sequence from radio-wave velocity measurements}

Analysis of deep ice cores from the temperate Amundsenisen and the two-layered Fridtjovbreen (Zagorodnov and Zotikov, 1981; Zagorodnov and others, 1985) and of 


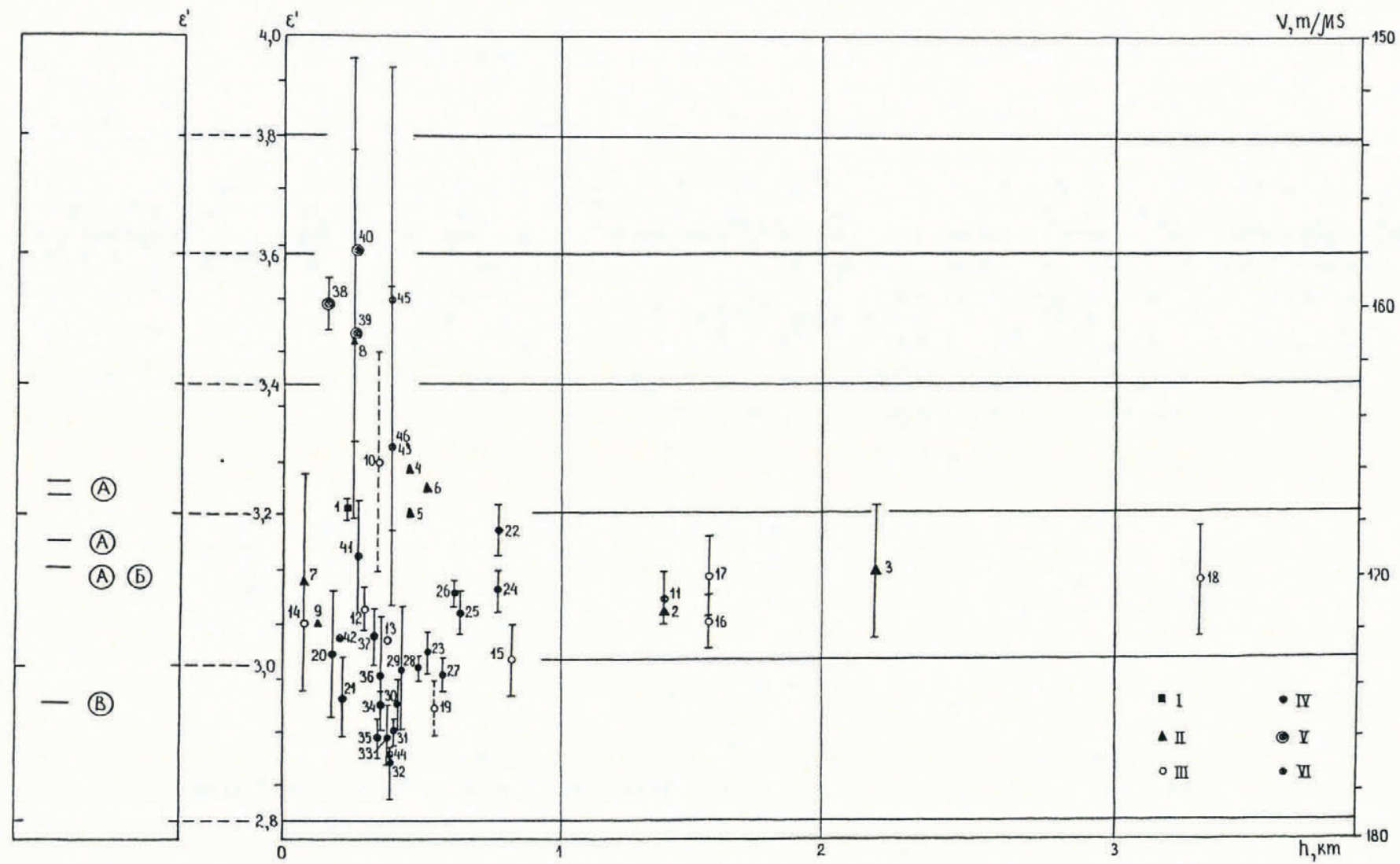

Fig. 7. Comparison of field-measurement data on radio-wave velocities $V$ in glaciers (a) and laboratory-measurement data of dielectric permittivity $\epsilon$ of glacier ice (b). From Bogorodskiy and others (1983, table 3), with some changes and additions. Methods and regions of measurements:

1. Radio-interferometry of borehole: 1. Canadian Arctic Archipelago, Devon Ice Cap (Robin, 1975b).

II. Radio-echo sounding near a borehole drilled to bedrock: 2. Greenland, Camp Century station (Bogorodskiy and others, 1983; G. de Q. Robin's data); 3. Antarctica, Byrd Station (Drewry, 1975); 4, 5 and 6. Severnaya Zemlya, Vavilov Glacier (Bogorodskiy and others, 1983); 7. Tien Shan, Karabatkak Glacier (Ryumin and Zverev, 1969); 8 and 9. Spitsbergen: Fridtjovbreen, borehole 1 (see Fig. 1b) (Macheret and others, 1980) and Bertilbreen (Zhuravlev and others, 1983).

III. Wide-angle reflection measurements on ground glaciers: 10 and 11. Greenland, Tuto East station (Robin and others, 1969) and Camp Century station (Bogorodskiy and others, 1983); 12. Baffin Island, Barnes Ice Cap (Clough and Bentley, 1970); 13. Severnaya Zemlya, Vavilov Glacier (Fedorov, 1978); 14. Tien Shan, Tuyuksu Glacier (Epov, 1984); 15-19. Antarctica: Roosevelt Island (15) (Firacek and Bentley, 1971; Jezek and others, 1978), Dronning Maud Land, station 840 (16, 17) (Clough and Bentley, 1970), Dome C (18) (Bogorodskiy and others, 1983), Embulisen-Troltunga glaciers (19) (Van Autenboer and Decleir, 1969).

IV. Wide-angle reflection measurements on ice shelves in Antarctica: 20-22. McMurdo Ice Shelf (Firacek and Bentley, 1971; Jezek and others, 1978); 23-36. Ross Ice Shelf (Jezek and others, 1978); 37. Fimbulisen ice shelf (Jezek and others, 1978).

$V, V I$ and VII. Wide-angle reflection measurements on glaciers which are considered as temperate (V, VI) and sub-polar (VII) ones, respectively: 38 - 40. Abramov Glacier (see Table 3), site 1: $V_{\mathrm{m}}(38)$, site 2: $V_{\mathrm{m}}(39)$ and $V_{2}(40)$; $41-$ 43. Fridtjovbreen (see Table 3), site 3: $V_{\mathrm{m}}$ (41); $V_{1}$ (42) and $V_{2}$ (43); 44 48. Hansbreen (see Table 3), site 4: $V_{\mathrm{m}}$ (44), $V_{1}$ (45) and $V_{2}$ (46) for model 1 (see Fig. 6a), $V_{1}$ (47) and $V_{2}$ (48) for model 2 (see Fig. 6b); 49-51. Vernagtferner (Blindow and Thyssen, 1986), site CMP1 (accumulation area): $V_{\mathrm{m}}(49)$ and $V_{2}$ (50), site CMP2 (below equilibrium line): $V_{\mathrm{m}}$ (51).

Data of laboratory measurements on ice samples: W-P, Westfal (Bogorodskiy and others, 1983); F, Fitzgerald and Paren (1975); P, Paren and Glen (1978).

Continuous lines show the errors of field measurements of radio-wave velocity with correction because of density change in the near-surface snow-firn layer; dotted lines show errors without this correction. The symbol $\times$ marks the velocity in temperate ice.

speleological studies within several Spitsbergen glaciers (Schroeder, 1990; personal communication from J. Jania and M. Pulina) has shown that water inclusions are concentrated in channels and cavities of different orientation and size. These inclusions may be approxim- ated as both spherical and randomly distributed linear bodies. Air inclusions can also be considered as bodies of the same form. Therefore, for a quantitative description of the dependence of dielectric permittivity $\epsilon$ of dry and wet ice and firn of density $\rho$ and water content $W$, we assume 
that these media are two-component heterogeneous mixtures, in which the size of inclusions is much less than the wavelength $\lambda$ of the radar, and use the simple formulas given by Smith and Evans (1972) and Robin and others (1969) which are valid for these two limiting cases.

In the first case, the Looyenga mixture formula (Looyenga, 1965), which is valid for large concentrations of spherical air and water inclusions in ice, is applied:

$$
\begin{gathered}
\epsilon_{\mathrm{d}}^{1 / 3}=1+\theta\left(\epsilon_{\mathrm{i}}^{1 / 3}-1\right), \\
\epsilon_{\mathrm{s}}^{1 / 3}=\epsilon_{\mathrm{d}}^{1 / 3}+(1-\theta)\left(\epsilon_{\mathrm{w}}^{1 / 3}-\epsilon_{\mathrm{d}}^{1 / 3}\right)
\end{gathered}
$$

where subscripts $d, s, i$ and $w$ denote correspondingly dry and wet glacier ice or firn, dry solid ice $\left(\rho_{\mathrm{i}}=917 \mathrm{~kg} \mathrm{~m}^{-3}\right)$ and water by volume, and $\theta=\rho_{\mathrm{d}} / \rho_{\mathrm{i}},(1-\theta) \times 100=W$ is water content expressed as a percentage. If $\rho_{\mathrm{d}}>$ $300 \mathrm{~kg} \mathrm{~m}^{-3}$, a good approximation of Equation (8) and laboratory measurement data for $\epsilon$ is given by the empirical formula of Robin and others (1969) (see Bogorodskiy and others, 1983):

$$
\sqrt{\epsilon_{\mathrm{d}}}=1+0.00085 \rho_{\mathrm{d}} \text {. }
$$

In the second case, when water inclusions are distributed randomly throughout the ice, Paren's mixture formula (see Smith and Evans, 1972) is used:

$$
\epsilon_{\mathrm{s}}=\epsilon_{\mathrm{d}}+\frac{1}{3}(1-\theta) \epsilon_{\mathrm{w}} \text {. }
$$

It follows from Equations (8) and (9) that

$$
\begin{gathered}
\rho_{\mathrm{d}}=\rho_{\mathrm{i}} \frac{\left(c / V_{\mathrm{d}}\right)^{2 / 3}-1}{\epsilon_{\mathrm{i}}^{1 / 3}-1}, \\
W=\frac{\left(c / V_{\mathrm{s}}\right)^{2 / 3}-\epsilon_{\mathrm{d}}^{1 / 3}}{\epsilon_{\mathrm{i}}^{1 / 3}-\epsilon_{\mathrm{d}}^{1 / 3}} \times 100
\end{gathered}
$$

and from Equations (10) and (11) that

$$
\begin{gathered}
\rho_{\mathrm{d}}=\frac{c / V_{\mathrm{d}}-1}{0.00085}, \\
W=300 \frac{\left(c / V_{\mathrm{s}}\right)^{2}-\epsilon_{\mathrm{d}}}{\epsilon_{\mathrm{w}}}
\end{gathered}
$$

where $V_{\mathrm{d}}$ and $V_{\mathrm{s}}$ are velocities corresponding to cold and temperate ice masses. When used with the data given above, we assume $\epsilon_{\mathrm{i}}=3.2$ and $\epsilon_{\mathrm{w}}=86$.

\section{Average density of cold ice}

This parameter can be estimated directly from Equations (12) and (14) using the measured value of $V_{\mathrm{d}}$. The results of this calculation of $\rho_{\mathrm{i}}$ for the upper layer of cold ice on Fridtjovbreen and Hansbreen (sites 3 and 4) are given in Table 3.

Direct measurements of the ice-core density from borehole 2 to a depth of $119 \mathrm{~m}$ on Fridtjovbreen give an average integral ice density $\bar{\rho}_{\mathrm{d}}=904 \mathrm{~kg} \mathrm{~m}^{-3}$ (Macheret and others, 1985a). This implies an error in the estimation of density $\rho_{1}$ of layer 1 (Fig. 6a) by Equations (13) and (15) of +37 and $+31 \mathrm{~kg} \mathrm{~m}^{-3}$. Use of the same value $\bar{\rho}_{\mathrm{d}}$ for Hansbreen (site 4 ) gives a lower value of $\rho_{1}$.

\section{Water content}

For estimating water content in wet firn and ice from Equations (12) and (14), it is necessary to know the average density $\rho_{\mathrm{d}}$ of dry firn and ice.

On Abramov Glacier, a study of the ice core at site 1 from the depth interval of $31.6-105.6 \mathrm{~m}$ gives $\rho_{\mathrm{d}}=$ $908 \mathrm{~kg} \mathrm{~m}^{-3}$ (Krenke and Suslov, 1980). At site 2, taking into account snow-pit density measurements to a depth of $13.2 \mathrm{~m}$ (Krenke and Suslov, 1980). At site 2 taking into account snow-pit density measurements to a depth of $13.2 \mathrm{~m}$ (Krenke and Suslov, 1980) and further assuming a smooth increase in density with depth to a value of $908 \mathrm{~kg} \mathrm{~m}^{-3}$, the average densities of the whole snow-firn and glacier sequence are correspondingly 734 and $882 \mathrm{~kg} \mathrm{~m}^{-3}$.

Investigations of the ice core from borehole 2 on Fridtjovbreen showed that the dependence of ice density on depth $z$ is described by a function $\rho(z)=879.5 z^{0.0072}$ (Macheret and Zhuravlev, 1985), from which average ice density in the lower ice layer is equal to $912 \mathrm{~kg} \mathrm{~m}^{-3}$. The same density value can also be assumed for the lower ice layer on Hansbreen at site 4.

The above-mentioned values for firn and ice density $\rho_{\mathrm{d}}$ and the data of Table 2 were used to estimate mean water content $W$ in temperate firn and ice layers on Abramov Glacier, Fridtjovbreen and Hansbreen. The results of the calculations are given in Table 3. These show that estimated water content in the temperate ice of Abramov Glacier differs in both cases by more than $0.55 \%$ and is close to the results given by thermal-balance measurements on this glacier where this value is about $2 \%$ (Krenke and Suslov, 1980). The greatest difference between these equations is for the intermediate layer $1-2$ on Hansbreen (site 4).

\section{Variations of water content in glaciers}

From Table 3 it can be seen that estimations of $W$ in Abramov Glacier and in the lower layer of Fridtjovbreen and Hansbreen obtained here agree well with the present ideas of water content in temperate glaciers from $0.1 \%$ up to $1-2 \%$ (Golubev, 1976). The exception is the intermediate layer 1-2 on Hansbreen at site 4 where an anomalously high value of $W$ was estimated at about 4 $5 \%$. The most probable cause of this is the existence of cavities and channels within the glacier ice with water accumulations remaining during the winter below the boundary between cold and temperate ice, the depth of which, as shown by investigations on Fridtjovbreen (see above), is close to the IRH depth.

Bamber (1987) has shown that the IRH level in twolayered glaciers on Spitsbergen is well described by the piezometric surface of Röthlisberger channels (Röthliseason, are hypothesized to be the residues of a large-scale network of conduits which drain the surface meltwaters to one or more channels at depth. Some of these are closed off in the winter and water is trapped in cavities which remain in the ice at the melting-point temperature (Bamber, 1988).

The data of airborne RES from 1983 (Bamber, 1987, 1989) showed that the power-reflection coefficient (PRC) from IRHs on the two-layered glaciers of Spitsbergen 
vary from -15 to $-30 \mathrm{~dB}$. Using Mie-scattering theory, Bamber (1988) showed that such high values of PRC at $60 \mathrm{MHz}$ are consistent with the presence of an ice layer below the IRH containing $1 \%$ by volume of spherical water inclusions approximately $0.25 \mathrm{~m}$ in radius. Since the size of these water inclusions is much less than the central wavelength of our radar $(\lambda=37.5 \mathrm{~m})$, the intermediate layer 1-2 in model (2) can be considered as consisting of a heterogeneous mixture of ice, air and water with an effective dielectric permittivity $\tilde{\epsilon}_{1-2}$ and plane boundaries. The PRC from such a boundary is calculated as

$$
R_{1,2}=20 \log _{10} \frac{\sqrt{\tilde{\epsilon}_{1-2}}-\sqrt{\tilde{\epsilon}_{1}}}{\sqrt{\tilde{\epsilon}_{1-2}}+\sqrt{\tilde{\epsilon}_{1}}}
$$

where, from Equation (7), $\sqrt{\tilde{\epsilon}_{1-2}}=c / V_{1-2}, \tilde{\epsilon}_{1}=c / V_{\mathrm{d}}, \tilde{\epsilon}_{1}$ is the effective dielectric permittivity of the lower part of the upper layer 1 consisting of cold ice with air bubbles and having a thickness of $\Delta h_{1}<\lambda_{\text {ice }}$, and $V_{\mathrm{d} 1}$ and $V_{1-2}$ are the RWV in the layers.

Using the data in Table 3 for site 4 on Hansbreen and Equation (16), $R_{1,2}=-20.3 \pm 1.2 \mathrm{~dB}$. Thus, the calculated value of $R_{1,2}$ is close to the average values of PRC from IRHs on two-layered glaciers of Spitsbergen (Bamber, 1987, 1989). Deviations of PRC from this value can be connected with variations in the size and content of water inclusions and, consequently, velocities $V_{8}$ in the lower layer of water-saturated ice which, with Equation (16), can be estimated as

$$
V_{\mathrm{s}}=V_{\mathrm{d}} \frac{1-10^{0.05 R_{1,2}}}{1+10^{0.05 R_{1,2}}}
$$

assuming that the error of determination of $R_{1,2}$ is small. For site 4 on Hansbreen, assuming $V_{\mathrm{d}}=176.8 \mathrm{~m} \mu \mathrm{s}^{-1}$ (see Table 3) and $R_{1,2}=-20$ to $-30 \mathrm{~dB}$, we get $V_{\mathrm{B}}=144.6$ to $166.0 \mathrm{~m} \mu \mathrm{s}^{-1}$. The velocities $V_{\mathrm{B}}$ are of the same order we obtained during the summer and spring measurements on Fridtjovbreen in borehole 2 and at site 3 . However, practical application of Equation (17) for estimating variations in $V_{\mathrm{s}}$ (and, consequently, variations of water content) from the data of PRC measurements at higher frequencies is difficult because of the broad range of PRC determinations - about $\pm 5 \mathrm{~dB}$ (Bamber, 1987, 1989; Macheret and Vasilenko, 1988).

It can be supposed that, as on Hansbreen at site 4, similar intermediate layers of water-saturated ice can be present in other Spitsbergen glaciers (Macheret, 1990; Macheret and others, 1991), i.e. these glaciers can have more complicated internal structures with an intermediate layer containing an increased content of water inclusions. Specifically, such an intermediate layer, apparently, can be proposed for Werensköldbreen where, during airborne RES in July 1979 and in September 1984, seasonal changes of the character of internal reflections were noticed and a series of reflections having quasi-hyperbolic form was noted and was probably connected with interglacial water accumulations. Short quasi-hyperbolic tracks of internal reflections below the IRH observed in the lower part of Fridtjovbreen (Macheret and Zhuravlev, 1985) can also be connected with water accumulations in the upper part of the temperate ice layer.
Seasonal and annual variations of water content in the glacier sequence can also be accounted for by the noticeable difference of RWVs in the lower layers of ice on Fridtjovbreen and Hansbreen (see Table 3), as well as for the difference in average velocities $V_{\mathrm{m}}$, measured on Fridtjovbreen at borehole 1 in the summer of $1977\left(V_{\mathrm{m}}=\right.$ $161.4 \mathrm{~m} \mu \mathrm{s}^{-1}$ ) (Macheret and others, 1980) and at WAR site 3 in the spring of $1988\left(V_{\mathrm{m}}=169.6 \pm 2.1 \mathrm{~m} \mu \mathrm{s}^{-1}\right)$ (see Table 3).

The above facts make it possible to consider repeated measurements of RWV in glaciers as a perspective for the study of seasonal and annual changes of their hydrothermal regime and water content. For this purpose, data of repeated PRC measurements from extended internal boundaries and the bottom of two-layered glaciers should be used. The available data on RWVs in two-layered subpolar and temperate glaciers (see Table 3 and Fig. 1) also provide a basis to express any views concerning peculiarities of their hydrothermal state and evolution.

The measurements carried out on Vernagtferner in March 1983 (Blindow and Thyssen, 1986) showed that in the accumulation area the RWV in ice underlying a snow-firn layer c. $20 \mathrm{~m}$ thick $V_{2}=165 \pm 1 \mathrm{~m} \mathrm{~s}^{-1}$ and, below the equilibrium line $V_{\mathrm{m}}=172 \pm 1 \mathrm{~m} \mu \mathrm{s}^{-1}$. These values of velocity are characteristic of temperate ice with a small water content and cold ice, respectively. Thus, Vernagtferner can be considered as polythermal. A noticeable difference in RWVs in the temperate ice of Vernagtferner and Fridtjovbreen, on the one hand, and of Abramov Glacier and Hansbreen, on the other, can be explained by them achieving different stages of evolution. Particularly, on Hansbreen there is a comparatively thick intermediate layer of temperate ice with an anomalously low RWV $\left(V_{1-2}=145.5 \pm 5.5 \mathrm{~m} \mu \mathrm{s}^{-1}\right)$, indicating that Hansbreen has a well-developed internal hydrological drainage system.

\section{CONGLUSIONS}

Wide-angle reflection measurements on temperate and sub-polar glaciers with records of returns from the bed and internal boundaries using HF monopulse equipment make it possible to measure with an accuracy of about $1 \%$ not only average radio-wave velocity and ice thickness but also to determine dielectric characteristics of the glacier sequence and to use them to estimate such important physical parameters as average density and water content. Specifically, on two-layered glaciers, low1 -equency studies make it possible to determine RWVs in he upper cold and lower temperate ice layers, to isolate horizons with different RWVs within the lower layer, as well as to estimate water content in these layers and horizons. In the accumulation areas of glaciers, including a firn zone, this method also makes it possible to estimate analogous parameters and the thickness of the snow-firn layer.

The high sensitivity of RWV, even to a small water - ontent in the glacier sequence, makes it possible to carry out regime observations on the change in water content in different parts of cold, sub-polar and temperate glaciers, and to characterize the hydrothermal state of glaciers or their individual parts. 


\section{ACKNOWLEDGEMENTS}

The authors are grateful to Dr A.F. Glazovskiy, Professor M. Pulina, Dr J. Jania and Dr P. Glawacki for considerable help in the field investigations and useful discussions of the results obtained.

\section{REFERENGES}

Autenboer, T. van and H. Decleir. 1969. Airborne radioglaciological investigations during the 1969 Belgian Antarctic Expedition. Bull. Soc. Belge Géol. Paléontol. Hydrol., 78(2), 87-100.

Bamber, J.L. 1987. Internal reflecting horizons in Spitsbergen glaciers. Ann. Glaciol., 9, 5-10.

Bamber, J.L. 1988. Enhanced radar scattering from water inclusions in ice. F. Glaciol., 34(118), 293-296.

Bamber, J. L. 1989. Ice/bed interface and englacial properties of Svalbard ice masses deduced from airborne radio echo-sounding data. F. Glaciol., 35(119), 30-37.

Beek, L. K. H. van. 1967. Dielectric behaviour of heterogeneous systems. In Birks, J. B., ed. Progress in dielectrics. Vol. 7. London, Heywood Books, 69-114.

Blindow, N. and F. Thyssen. 1986. Ice thickness and inner structure of the Vernagtferner (Ötztal Alps): results of electromagnetic reflection measurements. $Z$. Gletscherkd. Glazialgeol., 22(1), 43-60.

Bogorodskiy, V., C. Bentley and P. Gudmandsen. 1983. Radioglyatsiologiya [Radioglaciology]. Leningrad, Gidrometeoizdat.

Clough, J. W. and C. R. Bentley. 1970. Measurements of electromagnetic wave velocity in the East Antarctic ice sheet. International Association of Scientific Hydrology Publication 86 (Symposium at Hanover 1968-Antarctic Glaciological Exploration (ISAGE)), 115-128.

Dowdeswell, J.A., D.J. Drewry, O. Liestøl and O. Orheim. 1984a. Airborne radio echo sounding of subpolar glaciers in Spitsbergen. Nor. Polarinst. Skr. 182.

Dowdeswell, J.A., D.J. Drewry, O. Liestøl and O. Orheim. 1984b. Radio echo-sounding of Spitsbergen glaciers: problems in the interpretation of layer and bottom returns. F. Glaciol., 30(104), 16-21.

Drewry, D.J. 1975. Comparison of electromagnetic and seismic-gravity ice thickness measurements in East Antarctica. F. Glaciol., 15(73), 137-150.

Epov, A.B. 1984. Metod naklonnogo radiozondirovaniya pri issledovanii vnutrennego stroyeniya lednika Tsentral'nyy Tuyuksu [The method of oblique radio echo-sounding used for studies of the internal structure of central Tuyuksu glacier]. Mater. Glyatsiol. Issled. 50, 165-174.

Fedorov, B.A. 1978. Ob izmerenii sredney skorosti vertikal'nogo rasprostraneniya impul'snykh radiosignalov v lednikakh Severnoy Zemli [On measurement of mean velocity of vertical propagation of impulse radio signals in glaciers of Severnaya Zemlya]. Tr. Arkt. Antarkt. Nauchno-Issled. Inst., 359, 48-55.

Fitzgerald, W.J. and J.G. Paren. 1975. The dielectric properties of Antarctic ice. F. Glaciol., 15(73), 39-48.

Glazovskiy, A.F. and M.Yu. Moskalevskiy. 1989. Issledovaniya lednika Frit'of na Shpitsbergene v 1988 godu [Studies of Fridtjovbreen on Spitsbergen in 1988]. Mater. Glyatsiol. Issled. 65, 148-153.

Glazovskiy, A. F., L. Kolondra, M. Yu. Moskalevskiy and Ya. Yaniya. 1991a. Issledovaniya prilivnogo lednika Khansa na Shpitsbergene [Studies of the tide-water glacier Hansbreen on Spitsbergen]. Mater. Glyatsiol. Issled. 71, 143-149.

Glazovskiy, A. F., T. N. Konstantinova, Yu. Ya. Macheret, M. Yu. Moskalevskiy, L. I. Bobrova and L.V. Sankina. 1991b. Tolshchina l'da i podlednyy rel'yef lednika Frit'ofa po dannym nazemnoy radiolokatsionnoy s"yemki [Mapping ice thickness and subglacial relief of Fridtjovbreen from data of ground-based radio echo-sounding survey]. Mater. Glyatsiol. Issled. 72, 161166.

Golubev, G. N. 1976. Gidrologiya lednikov (The hydrology of glaciers). Leningrad, Gidrometeoizdat.

Gromyko, A. N., Ye. V. Vasilenko, Yu. Ya. Macheret and M.Yu. Moskalevskiy. 1989. Opyt ispol'zovaniya radiolokatora dlya izucheniya stroyeniya snezhnofirnovoy tolshchi [Experience in the use of radar for studying the structure of snow-firn sequence]. Mater. Glyatsiol. Issled. 66, 108-116.

Gurvich, I. I. 1975. Seismorazvedka [Seismic survey]. Moscow, Nedra.

Jacobel, R. W., S. K. Anderson and D. F. Rioux. 1988. A portable digital data-acquisition system for surfacebased ice-radar studies. F. Glaciol., 34(118), 349-354.

Jezek, K. C. and E. A. Roelofs. 1983. Measurements of radar wave speeds in polar glaciers using a down-hole radar target technique. Cold Reg. Sci. Technol., 8(2), 199-208.

Jezek, K. C., J. W. Clough, C. R. Bentley and S. Shabtaie. 1978. Dielectric permittivity of glacier ice measured in situ by radar wide-angle reflection. F. Glaciol., 21(85), 315-329.

Jiracek, G. R. and C.R. Bentley. 1971. Velocity of electromagnetic waves in Antarctic ice. Antarct. Res. Ser., 16, 199-208.

Kotlyakov, V. M. and Yu. Ya. Macheret. 1987. Radio echo-sounding of sub-polar glaciers in Svalbard: some problems and results of Soviet studies. Ann. Glaciol., 9, 151-159.

Krenke, A. N. and V. F. Suslov, eds. 1980. Lednik Abramova (Alayskiy Khrebet). Vodnoledovyy $i$ teplovoy balans gornolednikovykh basseynov [Water-ice and heat balance of Abramov glacier (Alai range)]. Leningrad, Gidrometeoizdat.

Looyenga, M. 1965. Dielectric constants of heterogeneous mixture. Physica, 31(3), 401-406.

Macheret, Yu. Ya. 1990. Two-layered glaciers in Svalbard. In Kotlyakov, V. M. and V.Ye. Sokolov, eds. Arctic research: advances and prospects. Proceedings of the Conference of Arctic and Nordic Countries on Coordination of Research in the Arctic, Leningrad, December 1988. Vol. 2. Moscow, Nauka, 58-60.

Macheret, Yu. Ya. and Ye. V. Vasilenko. 1988. Osobennosti vnutrennego stroyeniya i rezhima lednikov Severo-Vostochnoy Zemli po dannym aeroradiozondirovaniya [Features of the internal structure and regime of glaciers on Nordaustlandet from airborne radio echo-sounding data]. Mater. Glyatsiol. Issled. 63, 44-56.

Macheret, Yu. Ya. and A. B. Zhuravlev. 1981. Detal'naya 
radiolokatsionnaya s"yemka tolshchiny l'da podlednogo rel'yefa gornykh lednikov [Detailed radio echosounding survey of ice thickness and subglacial relief of mountain glaciers]. Mater. Glyatsiol. Issled. Khron. Obsuzhdeniya 41, 115-133.

Macheret, Yu. Ya. and A. B. Zhuravlev. 1985. Tolstchina ob"yem i stroyeniye lednikov [Thickness, volume and structure of glaciers]. In Kotlyakov, V.M., ed. Glyatsiologiya Shpitsbergena [Glaciology of Spitsbergen]. Moscow, Nauka.

Macheret, Yu. Ya., A. B. Zhuravlev and A. N. Gromyko. 1980. Radiolokatsionnye issledovaniya lednikov Shpitsbergena v 1977 godu [Radio echo-sounding studies of Spitsbergen glaciers in 1977]. Mater. Glyatsiol. Issled. Khron. Obsuzhdeniya 38, 279-286.

Macheret, Yu. Ya., Ye. V. Vasilenko, A. N. Gromyko and A. B. Zhuravlev. 1984a. Radiolokatsionnyy karotazh skvazhiny na lednike Frit'of, Shpitsbergen [Radio-echo logging of the bore hole on Fridtjovbreen, Spitsbergen]. Mater. Glyatsiol. Issled. 50, 198-203.

Macheret, Yu. Ya., A. B. Zhuravlev and L. I. Bobrova. 1984b. Tolshchina, podlednyy rel'yef i ob"yem lednikov Shpitsbergena po dannym radiozondirovaniya [Thickness, subglacial relief and volume of Svalbard glaciers from radio echo-sounding data]. Mater. Glyatsiol. Issled. 51, 49-63.

Macheret, Yu. Ya., V.S. Zagorodnov, Ye. V. Vasilenko, A. N. Gromyko and A. B. Zhuravlev. 1985a. Issledovaniye prirody vnutrennikh radiolokatsionnykh otrazheniy na subpolyarnom lednike [Study of the nature of internal radar reflections on a subpolar glacier]. Mater. Glyatsiol. Issled. 54, 120-130.

Macheret, Yu. Ya., Ye V. Vasilenko, A. N. Gromyko and A. B. Zhuravlev. 1985b. Izmeneniye skorosti radiovoln po glubine subpolarnogo lednika [Change of radio wave velocity through the depth of a subpolar glacier]. Tr. Arkt. Antarkt. Nauchno-Issled. Inst., 395, 81-89.

Macheret, Yu. Ya., L. I Bobrova and L. V. Sankina. 1991. Ob"yemnoye gidrotermicheskoye sostoyaniye i rezhim lednikov Shpitsbergena po dannym aeroradiozondirovaniya [Volumetric hydrothermal state and regime of the Spitsbergen glaciers from airborne radio echo-sounding data]. Mater. Glyatsiol. Issled. 71, 40-53.

Paren, J. G. and J. W. Glen. 1978. Electrical behaviour of finely divided ice. F. Glaciol., 21(85), 173-191.

Robin, G.de Q. 1975a. Radio-echo sounding: glaciological interpretations and applications. F. Glaciol., 15(73), 49-64.

Robin, G.de Q. 1975b. Velocity of radio waves in ice by means of a bore-hole interferometric technique. $\mathcal{J}$. Glaciol., 15(73), 151-159.

Robin, G.de Q., S. Evans and J. T. Bailey. 1969. Interpretation of radio echo sounding in polar ice sheets. Philos. Trans. R. Soc. London, Ser. A, 265(1166), 437-505.
Röthlisberger, H. 1972. Water pressure in intra- and subglacial channels. F. Glaciol., 11(62), 177-203.

Ryumin, A. K. and V.B. Zverev. 1969. Radiolokatsionnoye zondirovaniye gornykh lednikov [Radio echosounding of mountain glaciers]. Vestn. Leningradskogo Universiteta, 1969 (6), 152-160.

Schroeder, J. 1990. Inside the glaciers-Svalbard, Norway. Canadian Caver, 22(1), 11-15.

Smith, B. M.E. and S. Evans. 1972. Radio echo sounding: absorption and scattering by water inclusions and ice lenses. 7. Glaciol., 11(61), 133-146.

Trepov, G. V. 1970. Izmereniye skorosti rasprostraneniya elektromagnitnykh voln $\mathrm{v}$ lednike [Measurements of velocity of propagation of electromagnetic waves in glaciers]. Tr. Arkt. Antarkt. Nauchno-Issled. Inst., 290, 60-63.

Vasilenko, Ye.V., A. N. Gromyko and Yu. Ya. Macheret. 1987. Opyt primeneniya nizkochastotnoy radiolokatsionnnoy apparatury dlya zondirovaniya lednikov Tyan'-Shanya i Shpitsbergena [Experience in the use of low-frequency radar for echo-sounding of Tyan'Shan and Spitsbergen glaciers]. Mater. Glyatsiol. Issled. 60, 193-199.

Vasilenko, Ye. V. and 6 others. 1988a. Radiolokatsionnaya s"yemka lednika Abramova nizkochastotnym lokatorom [Radio-echo surveys of Abramov glacier by lowfrequency radar]. Mater. Glyatsiol. Issled. 64, 174-182.

Vasilenko, Ye. V., A. N. Gromyko, D. N. Dmitriyev and Yu. Ya. Macheret. 1988b. Stroyeniye lednika Davydova po dannym radiozondirovaniya i termobureniya [The structure of the Davydov glacier from the data of radio echo-sounding and thermo-drilling]. Mater. Glyatsiol. Issled. 62, 208-215.

Watts, R.D. and A.W. England. 1976. Radio-echo sounding of temperate glaciers: ice properties and sounder design criteria. F. Glaciol., 17(75), 39-48.

Zagorodnov, V.S. and I. A. Zotikov. 1981. Kernovoye bureniye na Shpitsbergene [Ice core drilling on Spitsbergen]. Mater. Glyatsiol. Issled. Khron. Obsuzhdeniya 40, 157-163.

Zagorodnov, V.S., S. M. Archipov and Yu. Ya. Macheret. 1985. Rekonstruktsiya usloviy l'doobrazovaniya na subpolyarnom lednike po rezul'tatam issledovaniya kerna [Reconstruction of ice formation conditions on a subpolar glacier from the results of core studies]. Mater. Glyatsiol. Issled. 53, 36-44.

Zhuravlev, A. B., Yu. Ya. Macheret and L. I. Bobrova. 1983. Radiolokatsionnnye issledovaniya na polarnom lednike s zimnim stokom [Radar studies on a polar glacier with winter runoff]. Mater. Glyatsiol. Issled. Khron. Obsuzhdeniya 46, 143-149.

The accuracy of references in the text and in this list is the responsibility of the authors, to whom queries should be addressed. 